\title{
Faktor - Faktor yang Mempengaruhi Pandemic Incubation Program (PIP) Terhadap Keberlanjutan Usaha Mikro, Kecil dan Menengah di Kota Denpasar
}

\author{
I Gede Bagus Dera Setiawan ${ }^{1}$, Ni Wayan Purnami Rusadi², \\ Desak Made Indah Paramitha Sari ${ }^{3}$ \\ Politeknik Nasional Denpasar \\ Email: derabagus666@gmail.com
}

\begin{abstract}
The current Covid-19 pandemic has certainly resulted in the weakening of various economic sectors throughout the world, including in Bali, with the tourism sector as the main source of income for the community. As of April 13, 2020, the number of employees who have been laid off has reached 800 and 46,000 employees have been laid off. Most of them are employees in the tourism sector such as hotels and restaurants. Along with the increasing corona outbreak, the number of employees who have been laid off is increasing. On May 12, 2020, the number reached 2,189 people, while 65,594 employees were laid off. The high number of workers who were economically affected by the Pandemic in Denpasar City prompted the Denpasar City Government through the Denpasar City Tourism Office (DISPAR) to hold a Pandemic Incubation Program. This program is expected to be a solution to find other sources of income by building micro, small and medium enterprises. This study discusses the perceptions of participants and the factors that influence the PIP program on the sustainability of micro, small and medium enterprises in Denpasar City. The method used in this research is quantitative descriptive analysis, using the SEM-PLS analysis method. The sample in this study amounted to 105 participants who were selected purposively with the criteria of participants participating in the PIP program from start to finish for two months. The perception of PIP program participants is in the good category with a score of 3.66; while the participant's perception of the sustainability of micro, small and medium enterprises in Denpasar City got a score of 3.47 which is also included in the good category. The results of the analysis also show that the PIP program has a positive and significant relationship with the continuation of micro, small and medium enterprises in Denpasar City.
\end{abstract}

Ketywords : Factors, Pandemic Incubation Program, MSME

Abstrak

Pandemi Covid-19 yang terjadi saat ini tentunya mengakibatkan melemahnya berbagai sektor perekonomian di seluruh dunia termasuk di Bali dengan sektor pariwisata sebagai pendapatan utama masyarakat. Hingga 13 April 2020 jumlah karyawan yang di-PHK jumlahnya mencapai 800 orang dan ada 46.000 karyawan yang dirumahkan. Sebagian besar dari mereka adalah pegawai di sektor pariwisata seperti hotel dan restoran. Seiring dengan semakin meningkatnya wabah corona, jumlah karyawan yang di-PHK semakin bertambah. Pada 12 Mei 2020 jumlahnya mencapai 2.189 orang, sedangkan karyawan yang dirumahkan sebanyak 65.594 orang. Tingginya angka tenaga kerja yang terdampak secara ekonomi pada Pandemi di Kota Denpasar mendorong Pemerintah Kota Denpasar melalui Dinas Pariwisata (DISPAR) Kota Denpasar menggelar Pandemic Incubation Program. Program ini diharapkan mampu menjadi solusi untuk mencari sumber pendapatan lain dengan membangun usaha mikro, kecil dan menengah. Penelitian ini membahas tentang persepsi peserta serta faktor - faktor yang mempengaruhi program PIP terhadap keberlanjutan usaha mikro, kecil dan menengah di Kota Denpasar. Metode yang digunakan dalam penelitian ini adalah analisis deskriptif kuantitatif, menggunakan metode analisis SEMPLS. Sampel dalam penelitian ini berjumlah 105 orang peserta yang dipilih secara purposive dengan kriteria peserta yang mengikuti program PIP dari awal hingga selesai selama dua bulan. Persepsi peserta program PIP termasuk dalam kategori baik dengan skor sebesar 3,66; sedangkan persepsi peserta terhadap keberlanjutan usaha mikro, kecil dan menengah di Kota Denpasar mendapatkan skor sebesar 3,47 yang juga termasuk dalam kategori baik. Hasil analisis juga menunjukkan bahwa program PIP memiliki hubungan yang positif dan signifikan terhadap kelanjutan usaha mikro, kecil dan menengah di Kota Denpasar.

Kata Kunci: Faktor-faktor, Pandemic Incubation Program, UMKM

(C) 2021 Jurnal Riset Inspirasi Manajemen dan Kewirausahaan 


\section{PENDAHULUAN}

Pandemi Covid-19 yang terjadi saat ini tentunya mengakibatkan melemahnya berbagai sektor perekonomian di seluruh dunia termasuk di Bali dengan sektor pariwisata sebagai pendapatan utama masyarakat. Hingga 13 April 2020 jumlah karyawan yang di-PHK jumlahnya mencapai 800 orang dan ada 46.000 karyawan yang dirumahkan. Sebagian besar dari mereka adalah pegawai di sektor pariwisata seperti hotel dan restoran (Kompas.com, 2020). Seiring dengan semakin meningkatnya wabah corona, jumlah karyawan yang di-PHK semakin bertambah. Pada 12 Mei 2020 jumlahnya mencapai 2.189 orang, sedangkan karyawan yang dirumahkan sebanyak 65.594 orang (Merdeka.com, 2020).

Tingginya angka tenaga kerja yang terdampak secara ekonomi pada Pandemi di Kota Denpasar mendorong Pemerintah Kota Denpasar melalui Dinas Pariwisata (DISPAR) Kota Denpasar menggelar Pandemic Incubation Program. Program ini diharapkan mampu menjadi solusi untuk mencari sumber pendapatan lain dengan membangun usaha mikro, kecil dan menengah.

Pemerintah Kota Denpasar terus berupaya untuk mendukung pemulihan ekonomi di tengah pandemi saat ini. Meski wabah Covid-19 belum usai, inovasi guna mendukung pergerakan ekonomi terus dioptimalkan. Salah satunya dengan melaksanakan Pandemic Incubation Program (PIP). Program PIP ini bertujuan untuk memberikan stimulus produktif bagi masyarakat Kota Denpasar untuk memulai usaha, terutama bagi masyarakat yang terdampak pandemi Covid-19.

Pandemic Incubation Program (PIP) merupakan sebuah upaya untuk mendukung pemulihan ekonomi lewat usaha rintisan masyarakat. Dimana, kegiatan ini dikemas melalui pemberian Bantuan Stimulus Produktif sebesar Rp. 1.000.000,-, dimana pada PIP tahun 2020, telah lolos sebanyak 2.700 penerima stimulus produktif ini. Kegiatan pendampingan ini diharapkan juga bisa memberikan kesempatan bagi para pekerja yang terdampak untuk memutar kembali roda ekonomi mereka dengan memulai usaha tanpa perlu bergantung kembali pada pekerjaan lama mereka karena hidup akan terus berjalan meski kehidupan saat ini sedang sulit. Penelitian terkait Program PIP ini diharapkan mampu untuk memberikan gambaran mengenai persepsi masyarakat terdampak Covid-19 tentang Program PIP dan faktor - faktor yang mempengaruhi keberhasilan Program PIP di Kota Denpasar.

\section{KAJIAN LITERATUR}

\section{Pandemic Incubation Program (PIP)}

PIP merupakan program dari Pemerintah Kota Denpasar melalui Dinas Pariwisata Kota Denpasar yang berujuan untuk memberikan bantuan berupa stimulus produkti bagi masyarakat Kota Denpasar untuk memulai usaha, namun tidak menutup kemungkinan bagi para pelaku usaha juga mendapatkan bantuan stimulus tersebut berkaitan dengan keberlanjutan usaha mereka yang juga terdampak pandemi Covid-19.

Target peserta untuk program ini adalah sebanyak 1.700 orang dengan syarat memiliki KTP Kota Denpasar dengan masing - masing menerima bantuan dana sebesar Rp. 1.000.000,- dengan kategori penerima adalah masyarakat disabilitas dan masyarakat umum. Dengan adanya stimulus yang diberikan oleh Pemerintah Kota Denpasar, diharapkan muncul ide - ide kreatif usaha mikro yang mungkin untuk dijalankan oleh peserta sebagai alternatif memperoleh penghasilan. Disamping itu, peserta juga akan diberikan motivasi tentang berwirausaha.

Dalam program ini juga akan diadakan workshop untuk memberikan bekal pengetahuan mengenai teknis produksi atau operasional dari usaha yang akan digeluti. Pembagian kelompok didasarkan kepada bidang usaha yang dipilih/diminati, yaitu:

1. Kuliner

2. Fashion-Garmen

3. Kerajinan

4. Perdagangan/Reseller

5. IT, Desain \& Multimedia

6. Pertanian

7. Jasa

Berdasarkan pembagian kelompok tersebut, narasumber juga dibagi menurut bidang - bidang pelaku/praktisi dari masing - masing bidang usaha. Praktisi/pelaku usaha tersebut akan memberikan sharing dari masing - masing bidang usaha dari sudut pandang yang berbeda. Selain memberikan materi tentang kewirausahaan dan sharing tentang usaha, peserta juga akan diberikan pelatihan tentang pemasaran/marketing. Materi pemasaran yang akan diberikan berupa workshop tentang social media marketing, desain dan foto produk, yang secara keseluruhan pendampingan akan diberikan selama tiga bulan untuk keseluruhan program.

\section{Partial Least Square (PLS)}

Ghozali (2006) menjelaskan bahwa PLS adalah metode analisis yang bersifat soft modeling karena tidak mengasumsikan data harus dengan pengukuran skala tertentu, yang berarti jumlah sampel dapat kecil (dibawah 100 sampel). 
Perbedaan mendasar PLS yang merupakan SEM berbasis varian dengan LISREL atau AMOS yang berbasis kovarian adalah tujuan penggunaannya. Dibandingkan dengan covariance based SEM (yang diwakili oleh software AMOS, LISREL dan EQS) component based PLS mampu menghindarkan dua masalah besar yang dihadapi oleh covariance based SEM yaitu inadmissible solution dan factor indeterminacy (Tenenhaus et al., 2005).

\section{Analisis Structural Equation Modelling (SEM)}

Dalam penelitian ini, analisis data dengan statistika digunakan SEM-PLS bantuan software Smart PLS. Keunggulan analisis dengan PLS menurut Wold (1985 dalam Ghozali 2011) menyatakan bahwa PLS merupakan metode analisis yang powerfull oleh karena tidak didasarkan banyak asumsi. Data tidak harus berdistribusi normal multivariate (indikator dengan skala kategori, ordinal, inteval, dan sampai ratio) dapat digunakan pada model yang sama, sampel tidak harus besar. PLS dapat menganalisis sekaligus konstruk yang dibentuk dengan indikator refleksif dan indikator formatif dan hal ini tidak mungkin dijalankan dalam CBSEM karena akan terjadi unidentified model.

Menurut Ghozali (2011) tujuan PLS adalah membantu peneliti untuk mendapatkan nilai variabel laten untuk tujuan prediksi. Variabel laten adalah linear agregat dari indikator-indikatornya. Weight estimate untuk menciptakan komponen skor variabel laten didapat berdasarkan bagaimana inner model (model struktural yang menghubungkan antar variabel laten) dan outter model (model pengukuran yaitu hubungan antara indikator dengan konstruknya) dispesifikasi. Hasilnya adalah residual variance dari variabel independen (keduanya variabel laten dan indikator) diminimumkan.

PLS menangani model reflektif dan formatif, bahkan konstruk dengan item (indikator) tunggal (Hair et al., 2010 dalam Ghozali, 2011). Konstruk reflektif mengasumsikan bahwa konstruk/variabel laten mempengaruhi indikator (arah hubungan kausalitas dari konstruk ke indikator). Konstruk formatif mengasumsikan bahwa indikator mempengaruhi konstruk/variabel laten (arah hubungan kausalitas dari indikator ke konstruk).

\section{Penelitian Terdahulu}

Hasil penelitian dari peneliti pendahulu yang berkaitan dengan topik adalah sebagai berikut:

1. I Komang Adi Wirawan, Ketut Sudibia, Ida Bagus Putu Purbadharmaja; Pengaruh Bantuan Dana Bergulir, Modal Kerja, Lokasi Pemasaran dan Kualitas Produk Terhadap Pendapatan Pelaku Umkm Sektor Industri Di Kota Denpasar. Hasil penelitian yang didapatkan adalah; 1. Dana bergulir, modal kerja, lokasi pemasaran, dan kualitas produk secara langsung berpengaruh positif dan signifikan terhadap pendapatan pelaku UMKM di Kota Denpasar. Sedangkan volume produksi tidak berpengaruh signifikan terhadap pendapatan pelaku UMKM di Kota Denpasar; 2. Dana bergulir dan modal kerja secara tidak langsung tidak berpengaruh signifikan terhadap pendapatan pelaku UMKM di Kota Denpasar melalui volume produksi; dan 3 . Modal kerja berpengaruh paling dominan terhadap pendapatan pelaku UMKM di Kota Denpasar.

2. Andi Amri; Dampak Covid-19 Terhadap UMKM di Indonesia. Hasil penelitian adalah; 1. Kondisi UMKM ditengah pandemi terus mengalami penurunan kapasitas, mulai dari kapasitas produksi hingga penurunan penghasilan; dan 2. Perlu adanya kebijakan dalam rangka melindungi UMKM agar tetap bisa kompetitif meskipun ditengah pandemi Covid-19.

3. Aknolt Kristian Pakpahan; Covid-19 dan Implikasi Bagi Usaha Mikro, Kecil, dan Menengah. Hasil penelitian adalah bantuan keuangan baik dalam bentuk pinjaman lunak atau bantuan tunai langsung dengan melibatkan pemerintah dan sektor swasta. Sementara strategi jangka panjang difokuskan pada pengenalan dan penggunaan teknologi digital bagi UMKM sekaligus persiapan untuk memasuki era Industri 4.0.

\section{METODE PENELITIAN}

Program PIP merupakan program yang digagas oleh Dinas Pariwisata Kota Denpasar dalam rangka pemberian pembekalan kepada usaha mikro, kecil dan menengah di Kota Denpasar. Pembekalan yang dimaksud adalah sharing ilmu bisnis, pembelajaran tentang digital marketing/pemasaran produk secara online, sharing dan pendampingan dengan praktisi UMKM, serta pemberian stimulus kepada pelaku UMKM sebesar Rp. 1.000.000,kepada peserta program PIP. Program PIP diharapkan memiliki pengaruh yang positif terhadap keberlanjutan usaha mikro, kecil dan menengah di Kota Denpasar.

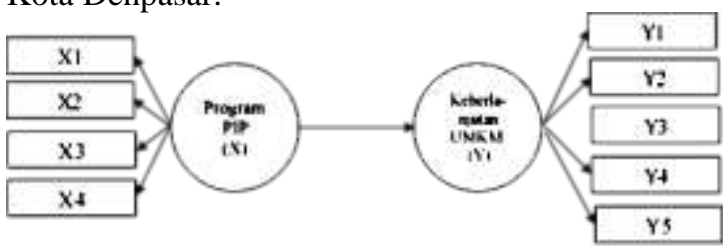

Gambar.1 Kerangka Konseptual 
Penelitian dilakukan di Kota Denpasar, dimana program PIP dilakukan pada tahun 2020. Waktu penelitian dilakukan selama tiga bulan selama bulan April - Juli 2021. Populasi penelitian ini adalah seluruh UMKM yang terdaftar pada program PIP tahun 2020 yaitu sebanyak 2.700 UMKM. Teknik pengambilan sampel dalam penelitian ini adalah dengan menggunakan teknik nonprobability sampling, yaitu sampling kebetulan (insidental/accidental sampling). Menurut Sugiyono (2017), sampling insidental adalah teknik penentuan sampel berdasarkan kebetulan, yaitu siapa saja yang secara kebetulan/insidental bertemu dengan peneliti dapat digunakan sebagai sampel, bila dipandang orang yang kebetulan ditemui itu cocok sebagai sumber data. Oleh karena situasi pandemi dan metode penyebaran kuesioner yang dilakukan secara online, maka jumlah kuesioner yang kembali menjadi sampel penelitian, dimana sampel penelitian ditetapkan menjadi 104 UMKM. Instrument penelitian yang digunakan dalam penelitian ini adalah kuesioner online menggunakan google document dengan ketentuan sebagai berikut:

1. Jawaban (a) sangat baik, dengan perolehan skor 5

2. Jawaban (b) baik, dengan perolehan skor 4

3. Jawaban (c) cukup, dengan perolehan skor 3

4. Jawaban (d) kurang, dengan perolehan skor 2

5. Jawaban (e) sangat kurang, dengan perolehan skor 1

Metode analisis data yang digunakan adalah uji validitas dan reliabiltas instrumen, analisa deskriptif dan analisis structural equation modelling (SEM) menggunakan software Partial Least Square (PLS) versi 3.0. Keunggulan analisis dengan PLS menurut Wold (1985, dalam Ghozali 2011) menyatakan bahwa PLS merupakan metode analisis yang powerfull oleh karena tidak didasarkan banyak asumsi. Data tidak harus berdistribusi normal multivariate (indikator dengan skala kategori, ordinal, inteval, dan sampai ratio) dapat digunakan pada model yang sama, sampel tidak harus besar. PLS dapat menganalisis sekaligus konstruk yang dibentuk dengan indikator refleksif dan indikator formatif dan hal ini tidak mungkin dijalankan dalam CBSEM karena akan terjadi unidentified model. Hipotesis yang dapat dirumuskan dari uraian sebelumnya adalah PIP berpengaruh secara positif dan signifikan terhadap keberlangsungan usaha di Kota Denpasar.

\section{HASIL DAN PEMBAHASAN}

\section{Evaluasi Model Pengukuran (Outer Model)}

Evaluasi model pengukuran memeriksa validitas dan reliabilitas indikator - indikator yang mengukur konstruk atau variabel laten. Dalam penelitian ini program PIP (X) dan Keberlanjutan Usaha (Y) merupakan model pengukuran dengan indikator reflektif sehingga dalam evaluasi model pengukuran dilakukan dengan memeriksa convergent dan discriminant validity dari indikator serta composite reliability.

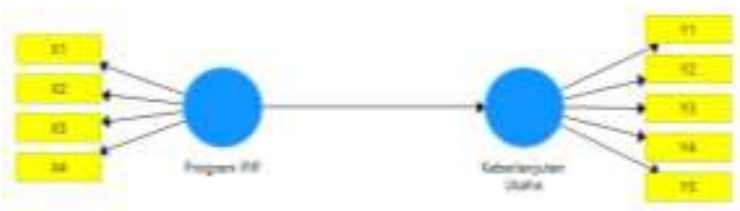

Gambar 2 Model Struktural

Dari tabel 1, ke semua indikator memiliki nilai outer loading lebih besar dari 0,70. Hasil ini menunjukkan bahwa seluruh parameter yang diujikan merupakan parameter yang valid dari indikator keberlanjutan usaha UMKM di Kota Denpasar.

Tabel 1. Pengujian Outer Model

\begin{tabular}{|c|c|c|}
\hline Vaniabel & Indikatur & Nilni Outer Model \\
\hline Proeram PIP (X) & 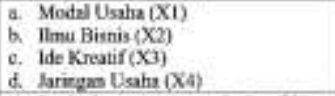 & $\begin{array}{l}0,958 \\
0,799 \\
0,882 \\
0,912 \\
\end{array}$ \\
\hline $\begin{array}{l}\text { Kebertanjutan Usuls } \\
\text { (Y) }\end{array}$ & 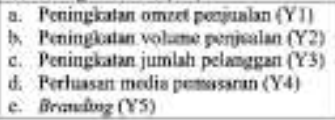 & $\begin{array}{l}0,910 \\
0,784 \\
0.877 \\
0,814 \\
0,733\end{array}$ \\
\hline
\end{tabular}

Sumber: Hasil Analisis Data Responden, 2021

\section{Discriminant Validity}

Evaluasi ini dilakukan dengan membandingkan nilai square root of average variance extracted (AVE) setiap variabel laten dengan korelasi antar variabel laten dalam model. Ketentuannya adalah apabila nilai $\sqrt{ } A V E$ variabel laten lebih besar dari nilai AVE mengindikasikan indikator-indikator variabel memiliki discriminant validity yang baik. Nilai $A V E$ direkomendasikan lebih besar dari 0,50.

Tabel 2, menunjukkan bahwa kedua variabel memiliki nilai $A V E$ berada diatas 0,50 dan nilai akar $A V E$ lebih tinggi daripada korelasi variabel laten. Hal ini berarti pengujian discriminant validity dengan akar AVE menunjukkan bahwa seluruh variabel diatas dikatakan baik / valid.

Tabel 2 Pemeriksaan Discriminant Validity

\begin{tabular}{llc}
\hline Variabel & $A V E$ & $\sqrt{ } A V E$ \\
\hline Program PIP (X) & 0,683 & 0,826 \\
Keberlanjutan Usaha UMKM (Y) & 0,791 & 0,889 \\
\hline Sumber : Hasil Analisis Data Responden 2021
\end{tabular}




\section{Composite Reliability dan Cronbach Alpha}

Evaluasi ini dilakukan dengan melihat nilai composite reliability dari blok indikator yang mengukur konstruk dan nilai cronbach alpha. Nilai composite reliability dan nilai cronbach alpha dikatakan baik apabila berada diatas 0,50. Hasil evaluasi nilai composite reliability dan cronbach alpha pada Tabel 3 menunjukkan bahwa ketiga variabel laten berada diatas 0,50 , sehingga dapat dinyatakan bahwa blok indikator reliabel atau handal mengukur variabel-variabel penelitian. Berdasarkan hasil evaluasi convergent dan discriminant validity masing-masing indikator maka dapat disimpulkan bahwa indikator-indikator tersebut dinyatakan valid dan reliabel. Berikut dapat dilihat nilai composite reliability dan nilai cronbach alpha pada Tabel 3.

Tabel 3 Pemeriksaan Discriminant Validity

\begin{tabular}{lll}
\hline \multicolumn{1}{c}{ Variabel } & $\begin{array}{l}\text { Composite } \\
\text { Reliability }\end{array}$ & $\begin{array}{c}\text { Cronbach } \\
\text { Alpha }\end{array}$ \\
\hline Program PIP (X) & 0,913 & 0,833 \\
Keberlanjutan Usaha & 0,938 & 0,911
\end{tabular}

UMUKM (Y)

Sumber : Hasil Analisis Data Responden, 2021

\section{Pengukuran model struktural (Inner Model)}

Pengujian model struktural untuk menilai efek dari setiap arah hubungan (causal path) dan pengujian hipotesis yang telah ditetapkan, digunakan teknik khusus SmartPLS yaitu teknik bootstrapping. Berdasarkan hasil analisis teknik tersebut, semua arah hubungan variabel signifikan pada tingkat signifikan ( $p$ value) 5\% dan dengan nilai t-statistik > 1,96. Semua hipotesis yang diajukan dapat diterima. Hubungan antar variabel seperti terlihat pada ilustrasi modelnya seperti Gambar 3.

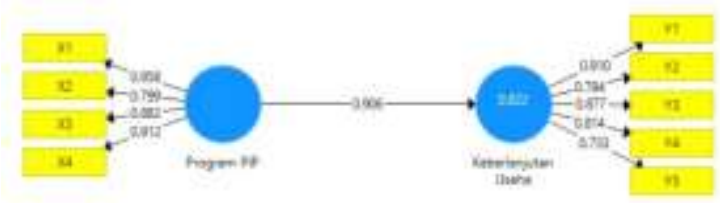

Dampak Program PIP terhadap Keberlanjutan Gambar 3. Rancangan model keberlanjutan usaha UMKM di Kota Denpasar dengan seluruh indicator reflektif yang valid

Tabel 3. Path Coefficients (Mean, STDEV, TValues)

\begin{tabular}{|c|c|c|c|c|c|}
\hline & $\begin{array}{l}\text { Original } \\
\text { Sumpite }\end{array}$ & $\begin{array}{l}\text { Sampie } \\
\text { Menm } \\
\text { (M) }\end{array}$ & $\begin{array}{l}\text { Standand } \\
\text { Devianiow } \\
\text { STDEVy }\end{array}$ & $\begin{array}{l}T \text {. } \\
\text { Swationie }\end{array}$ & $\begin{array}{l}P \\
\text { Valumen }\end{array}$ \\
\hline $\begin{array}{l}\text { Program PL } \rightarrow \\
\text { Ketberlanjutan Usaha }\end{array}$ & 0,906 & 0,908 & 0,024 & 38.215 & 0.000 \\
\hline
\end{tabular}

Sumber: Hasil Analisis Data Responden, 2021

\section{Kesesuaian Model}

Pada tahap akhir, dilakukan analisis kesesuaian model (model fit) menggunakan pendekatan statistik kesesuaian model (model fit statistics) yang meliputi Construct Crossvalidated Redundancy untuk inner model dan Construct Crossvalidated Communality untuk outer model. Berdasarkan data hasil analisis seperti terlihat pada Tabel 4 menunjukkan kesesuaian yang dapat diterima dan memiliki predictive relevance yang tinggi. Hal tersebut dibuktikan dari semua kriteria penilaian berupa nilai $\mathrm{Q}^{2}$ lebih dari 0 atau bernilai positif (Chin, 1998), serta Goodness of Fit untuk PLS-SEM yaitu SRMR (Sandardize Root Mean square Residual) < P Value 0,08 (Hu dan Bentler, 1999; Henseler et al., 2014), dimana model ini sudah memiliki kesesuaian untuk menggambarkan kondisi sebenarnya di lapangan dengan nilai SRMR sebesar 0,076.

Tabel 4. Statistik Kesesuaian Model Construct Crossvalidated Redundancy

\begin{tabular}{|l|l|l|l|}
\hline & SSO & SSE & Q2 (- 1-SSESSO) \\
\hline Koberlanjutan Usahs & 250,000 & 114,863 & 0,541 \\
\hline Program PIP & 200,000 & 200,000 & \\
\hline
\end{tabular}

Sumber: Hasil Analisis Data Responden, 2021

Tabel 5. Statistik Kesesuaian Model Construct Crossvalidated Communality

\begin{tabular}{|l|l|l|l|}
\hline & SSO & SSE & Q2(-1-SSESSO) \\
\hline Keberlanjutan Usahu & 250,000 & 118,769 & 0,525 \\
\hline Program PIP & 200,000 & 71.276 & 0,644 \\
\hline
\end{tabular}

Sumber: Hasil Analisis Data Responden, 2021

\section{Dampak Program PIP terhadap Keberlanjutan Usaha Kecil, Mikro dan Menengah di Kota Denpasar.}

Berdasarkan Gambar 3 diketahui bahwa secara bersama-sama bahwa variabel pengetahuan petani memiliki nilai koefisien determinan sebesar 0,882 . Hal ini menunjukkan bahwa variabel Program PIP menjelaskan variabel keberlanjutan usaha sebesar $88,2 \%$ dan sisanya sebesar $11,8 \%$ dijelaskan variabel diluar model. Selanjutnya dilakukan pengujian hipotesis dari jalur yang terbentuk dalam model yang dipaparkan pada uraian berikut:

Hubungan Program PIP terhadap Keberlanjutan Usaha Mikro, Kecil dan Menengah di Kota Denpasar. Motivasi petani (X) terbukti memiliki hubungan yang positif dan signifikan terhadap Keberlanjutan Usaha Mikro, Kecil dan Menengah di Kota Denpasar (Y). Hal ini ditunjukkan dengan nilai t-statistik sebesar 38,215 (t-statistik > 1,69). Sehingga hipotesis $1(\mathrm{H} 1)$ : program PIP memiliki hubungan positif terhadap Keberlanjutan Usaha Mikro, Kecil dan Menengah di Kota Denpasar dapat diterima. 


\section{KESIMPULAN DAN SARAN}

\section{Kesimpulan}

Berdasarkan pembahasan dan hasil analisis, kesimpulan yang didapatkan adalah:

1. Persepsi peserta terdampak Covid- 19 terhadap program PIP menunjukkan skor sebesar 3,66 yang termasuk kedalam kategori baik, sedangkan persepsi peserta terhadap keberlanjutan usaha mikro, kecil dan menengah di Kota Denpasar mendapatkan skor sebesar 3,47 yang juga termasuk dalam kategori baik.

2. Hubungan Program PIP terhadap Keberlanjutan Usaha Mikro, Kecil dan Menengah di Kota Denpasar. Motivasi petani (X) terbukti memiliki hubungan yang positif dan signifikan terhadap Keberlanjutan Usaha Mikro, Kecil dan Menengah di Kota Denpasar (Y). Hal ini ditunjukkan dengan nilai t-statistik sebesar 38,215 (t-statistik > 1,69). Sehingga hipotesis 1 (H1): program PIP memiliki hubungan positif terhadap Keberlanjutan Usaha Mikro, Kecil dan Menengah di Kota Denpasar dapat diterima.

\section{Saran}

Saran yang bisa disampaikan kepada beberapa pihak meliputi pemerintah dalam hal ini Pemerintah Kota Denpasar dan UMKM yang telah mengikuti Pandemic Incubation Program. Untuk pemerintah disarankan agar melaksanakan program ini secara berkesinambungan dan lebih menseleksi pendaftar agar peserta yang didapat sesuai dengan sasaran. Selain itu pemerintah juga diharapkan agar bisa mengalokasikan lebih tinggi dana stimulus yang diberikan dan membuatkan program lanjutan seperti kompetisi perkembangan usaha sebagai motivasi peserta yang sudah mengikuti program ini. Saran berikutnya untuk UMKM yang menjadi peserta PIP agar mengikuti program dengan sungguh - sungguh agar mendapatkan manfaat baik untuk bisnis ataupun personal. Para peserta juga disarankan agar menggunakan dana stimulus yang diberikan untuk usaha dan memanfaatkan pendampingan untuk memperluas jaringan pemasaran usaha.

\section{DAFTAR PUSTAKA}

Aknolt Kristian Pakpahan. 2020. Covid-19 dan Implikasi Bagi Usaha Mikro, Kecil, dan Menengah. Jurnal Ilmiah Hubungan
Internasional Edisi Khusus Vol. 0, Issue 0. https://journal.unpar.ac.id/index.php/JurnalIl miahHubunganInternasiona/article/view/387 0. Parahyangan Center for International Studies

Amri, Andi. 2020. Dampak Covid-19 Terhadap UMKM di Indonesia. Jurnal Brand Vol. 2 No. https://ejournals.umma.ac.id/index.php/bran $\mathrm{d} /$ index. Universitas Muslim Maros

Ghozali, Imam. 2006. Aplikasi Analisis Multivariate Dengan SPSS. Cetakan Keempat. Badan Penerbit Universitas Diponegoro. Semarang

Ghozali, Imam. 2011. Aplikasi Analisis Multivariate Dengan Program IBM SPSS 19 (Edisi Kelima). Semarang : Universitas Diponegoro

Rianse dan Abdi. 2012. Metodologi Penelitian Sosial dan Ekonomi: Teori dan Aplikasi. Bandung : Alfabeta

Siregar, Sofyan. 2013. Statistik Parametrik Untuk Penelitian Kuantitatif. Jakarta: PT. Bumi Aksara

Sugiyono. 2012. Memahami Penelitian Kualitatif. Bandung: Alfabeta.

Sugiyono. 2017. Metode Penelitian Kuantitatif, Kualitatif, dan R\&D. Bandung: Alfabeta, CV.

Tanenhaus, M.,. 2005. PLS Path Modeling : Computational Statistic and Data Analysis

Winarno, Budi. 2002. Teori dan Proses Kebijakan Publik. Yogyakarta: Media Pressindo.

Wirawan, I Komang Adi; Sudibia, Ketut; dan Purbadharmaja, Ida Bagus Putu. 2015. Pengaruh Bantuan Dana Bergulir, Modal Kerja, Lokasi Pemasaran dan Kualitas Produk Terhadap Pendapatan Pelaku Umkm Sektor Industri di Kota Denpasar. E-Jurnal Ekonomi dan Bisnis Vol. 4 Issue 1. https://ojs.unud.ac.id/index.php/EEB/article/ view/10476. Universitas Udayana

Profil Penulis

1. I Gede Bagus Dera Setiawan, S.P., M. Agb

Politeknik Nasional Denpasar

Email: derabagus666@gmail.com

2. Ni Wayan Purnami Rusadi S.P., M. Agb

Politeknik Nasional Denpasar

3. Desak Made Indah Paramitha Sari, S.E.., M.M

Politeknik Nasional Denpasar 